Groenewegen, P., Schäfer, W., Schellevis, F., Boerma, W. Kernwaarden van Nederlandse huisartsen in internationaal perspectief. Huisarts en Wetenschap: 2020: juli

Postprint version $\quad: \quad 1.0$

Journal website $\quad:$ https://www.henw.org/

\title{
Kernwaarden van Nederlandse huisartsen in internationaal perspectief
}

\author{
Peter Groenewegen, Willemijn Schäfer, François Schellevis, Wienke Boerma
}

\author{
Als huisarts doen we ons best om de kernwaarden van de huisartsenzorg in de praktijk \\ te brengen. Vergeleken met andere landen doen we dat goed. Dat blijkt uit een \\ analyse van een grootscheeps internationaal onderzoek onder huisartsen en hun \\ patiënten.
}

Een sterke eerstelijnszorg geldt als voorwaarde voor een effectief zorgstelsel. Sinds de verklaring van Alma Ata uit 1978 richten veel landen hun beleid op het bevorderen van de eerstelijnszorg. ${ }^{1-3}$ De grote verschillen in Europa qua financiering, organisatie en taakuitoefening van de eerstelijns- en huisartsenzorg bieden landen de mogelijkheid om van elkaar te leren. Een voorbeeld is de manier waarop landen invulling geven aan de poortwachtersrol van huisartsen. Lessen vallen ook te leren van de manier waarop patiënten de toegankelijkheid en continuïteit van de zorg ervaren als we kijken hoe landen verschillen in de manier waarop ze de eerstelijnszorg inrichten.

Om een betere vergelijking mogelijk te maken is tussen 2010 en 2014 in 34 meest Europese landen, waaronder Nederland, een groot onderzoek uitgevoerd onder huisartsen en hun patiënten. Sinds dat onderzoek zijn er geen recentere gegevens met dezelfde methoden op deze schaal verzameld. Via enquêtes in de landstaal werden gegevens verzameld over de praktijkorganisatie en de taakomvang van huisartsen, en ervaringen van patiënten met de zorgverlening. Het onderzoek mondde uit in een aantal publicaties. ${ }^{4}$ In dit artikel vatten we een aantal resultaten van dit onderzoek samen om na te gaan of deze gevolgen hebben voor de (herijkte) kernwaarden van de Nederlandse huisartsenzorg. Zo brengen we niet alleen mogelijke verbeterpunten aan het licht, maar laten we ook zien wat het behouden waard is.

In onze bespreking laten we zien welk verband er is tussen specifieke resultaten van het onderzoek en de herijkte kernwaarden van de huisartsenzorg, samengevat in de termen 'persoonsgericht', 'continu', 'medisch-generalistisch' en 'gezamenlijk'. ${ }^{5}$ Onze vraagstelling luidt: in hoeverre was de huisartsenzorg in 34 landen, waaronder Nederland, rond 2012 in lijn met de kernwaarden van de huisartsenzorg? Verschillen in de mate waarin de huisartsenzorg in een land spoort met de kernwaarden laten op een abstract niveau zien hoe goed dat land de huisartsenzorg op orde heeft.

\section{Methode}

In het grootscheepse QUALICOPC-onderzoek, onder leiding van het Nivel, verzamelden de onderzoekers met vragenlijsten gegevens onder 7183 huisartsen en 69.201 patiënten in 34 landen 
Groenewegen, P., Schäfer, W., Schellevis, F., Boerma, W. Kernwaarden van Nederlandse huisartsen in internationaal perspectief. Huisarts en Wetenschap: 2020: juli

(26 EU-lidstaten, IJsland, Noorwegen, Noord-Macedonië, Turkije, Zwitserland, Australië, Canada en Nieuw-Zeeland). ${ }^{6}$ In de meeste landen vulde een aselecte steekproef van huisartsen (één huisarts per praktijk) en hun patiënten vragenlijsten in. In landen waar nationale huisartsregisters niet beschikbaar waren, gebruikten de onderzoekers alternatieve methoden om een aselecte steekproef zo dicht mogelijk te benaderen. ${ }^{7}$ In Nederland vond een aselecte trekking van huisartsen plaats uit het bestand van de Nivel Beroepenregistraties in de Gezondheidszorg, waarna de huisartsen een brief of e-mail kregen met een verzoek tot deelname, gevolgd door (drie tot vijf) telefonische reminders. De enquêtes bevatten vragen over onder meer de praktijkorganisatie en taakprofielen van huisartsen, en de ervaringen van patiënten met het zojuist voltooide consult. ${ }^{8}$ De informatie uit de vragenlijsten voor huisartsen en uit die voor hun patiënten kon worden gekoppeld.

Onder de huisartsen was de deelname 38\%, variërend van minder dan 10\% in Oostenrijk en Zweden tot meer dan $70 \%$ in Griekenland en Spanje. In Nederland was de respons slechts $17 \%$ - wel waren de 238 deelnemende huisartsen qua leeftijd en geslacht representatief voor de huisartsenpopulatie. Van de responsgroep was $95 \%$ praktijkhouder, de rest had een dienstverband bij een gezondheidscentrum. De deelname onder de patiënten bedroeg 74\% (spreiding: 55-88\%). In Nederland vulden 2234 patiënten de vragenlijst in.

Ethische toetsing van het onderzoek vond plaats in overeenstemming met de wettelijke vereisten in elk deelnemend land.

Voor dit artikel haalden we de resultaten grotendeels uit de talrijke publicaties over het onderzoek en vulden we deze aan met enkele nog niet gepubliceerde gegevens.

\section{Wat is bekend?}

- Mede dankzij de poortwachtersfunctie en inschrijving op naam hebben Nederlandse huisartsen een sterke positie in het zorgstelsel

- Huisartsen hebben een breed zorgpakket en nemen een centrale positie in als coördinator van de zorg aan patiënten.

\section{Wat is nieuw?}

- Dit onderzoek bevestigt dat Nederlandse huisartsen een sterke rol spelen in het gezondheidszorgsysteem in vergelijking met 33 andere landen.

\section{Resultaten}

\section{Persoonsgerichte zorg}

Net als in andere landen ervaren Nederlandse patiënten de communicatie met de huisarts als zeer positief: $97 \%$ gaf te kennen dat de huisarts tijdens het consult aandachtig naar hen luisterde. ${ }^{9}$ Nederlandse patiënten zijn positief over hun betrokkenheid bij de beslissingen die tijdens het consult worden genomen. ${ }^{9}$ Dat geldt ook voor verwijsbeslissingen. Meer dan in enig ander land antwoorden Nederlandse huisartsen (92\%) dat ze een beslissing over een verwijzing samen met hun patiënt nemen [figuur 1]. De Nederlandse huisartsen betrekken de voorkeur van de patiënt ook vaker bij de keuze van een zorgaanbieder. Deze manier van werken bleek in landen met een poortwachterssysteem gebruikelijker dan in andere landen. ${ }^{10}$

De duur van een consult heeft invloed op de ruimte die er voor persoonsgerichtheid is, vooral wanneer het gaat om het exploreren van 'de vraag achter de vraag'. Met gemiddeld 11 minuten voor een enkel consult was een normaal spreekkamerconsult in 2012 kort; net als twintig jaar daarvóór [infographic en bijlage]. ${ }^{11}$ Van lang naar kort geordend staat Nederland op de 25e plaats, in de buurt 
Groenewegen, P., Schäfer, W., Schellevis, F., Boerma, W. Kernwaarden van Nederlandse huisartsen in internationaal perspectief. Huisarts en Wetenschap: 2020: juli

van Engeland en Oostenrijk. Scandinavische huisartsen hebben gemiddeld langere consulten, met uitzondering van Denemarken.

\section{[Figuur 1]}

\section{Toegankelijkheid en continuïteit}

De toegankelijkheid en continuïteit van de eerste lijn blijken van invloed op het zorggebruik van patiënten. Een goed toegankelijke eerste lijn waar continue zorg wordt geboden, gaat samen met minder bezoeken aan de spoedeisende hulp (SEH) van ziekenhuizen. In landen waar patiënten een 'eigen' huisarts hebben komen die minder vaak op de SEH. Het SEH-bezoek was in Nederland het op een na laagste ( $18 \%$ van de respondenten in een jaar, tegen ruim $29 \%$ gemiddeld in alle landen) [infographic en bijlage]. ${ }^{12}$

Van de Nederlandse patiënten gaf $85 \%$ aan dat hun huisarts hun persoonlijke situatie kent. Dit komt mogelijk doordat zij op naam staan ingeschreven bij hun huisarts, een belangrijke voorwaarde voor de continuïteit van zorg. Ook de beschikbaarheid en uitwisseling van informatie over patiënten en zorg kunnen de continuïteit enorm bevorderen. In Nederland (net als in de Scandinavische landen) is het bijhouden van het elektronisch patiëntendossier (EPD) dagelijkse routine. Dat is in Oost-Europese en enkele Zuid-Europese landen veel minder het geval.

Direct na hun bezoek aan de huisarts werd patiënten gevraagd wanneer zij de afspraak hadden gemaakt. Van de Nederlandse patiënten had $70 \%$ diezelfde dag of de dag ervoor afgesproken en $25 \%$ langer geleden [infographic en bijlage]. Op dit punt presteren Nederlandse huisartsen internationaal dus erg goed. ${ }^{13}$

Nederlandse huisartsenpraktijken zijn gemiddeld 10 uur per dag open, wat voor de meeste andere landen geldt [infographic en bijlage]. Openstelling van praktijken op avonden of in het weekend is in Nederland (in 2012) nog ongebruikelijk. Slechts $9 \%$ van de Nederlandse huisartsen gaf aan ten minste één keer per week na 6 uur's avonds of op een dag in het weekend spreekuur te houden. In bijna alle andere landen komt dit vaker voor, tot bijna $100 \%$ in Malta, Slovenië en België. ${ }^{11}$ Toch zijn Nederlandse patiënten zeer te spreken over de toegang tot de huisartsenzorg en zien ze op dit gebied weinig noodzaak tot verbetering. ${ }^{9}$ Ervaringen van patiënten met toegankelijkheid en continuïteit zijn in het algemeen positiever in landen waar huisartsen een breed taakprofiel hebben. ${ }^{14}$

In de zorg buiten kantooruren vormt de continuïteit in veel landen een punt. Nederland onderscheidt zich door een grotere betrokkenheid van huisartsen bij avond-, nacht- en weekenddiensten, in het bijzonder binnen de huisartsenposten. Elders hebben huisartsen deze diensten vaak overgedragen aan andere organisaties. ${ }^{11}$ In Nederland draagt dit mogelijk bij aan de als goed ervaren toegankelijkheid van de huisartsenzorg.

\section{Medisch-generalistische zorg}

In dit tijdschrift is het taakprofiel van Nederlandse huisartsen al eens vergeleken met dat van collega's in andere landen en zijn de ontwikkelingen beschreven die tussen 1992 en 2012 hebben plaatsgevonden. ${ }^{15}$ Hier vatten we die resultaten samen.

In 1993 - toen een Europees onderzoek onder huisartsen is gedaan - hadden Nederlandse huisartsen al een breder taakprofiel dan huisartsen in veel andere landen. In 2012 is dit in nog sterkere mate het geval. Het taakprofiel van Nederlandse huisartsen is verbreed op het gebied van de zorg voor patiënten met chronische ziekten. Eenzelfde trend is waarneembaar in de meeste andere landen. Anders dan in veel andere landen blijken de Nederlandse huisartsen actiever te zijn geworden op het terrein van preventie, vooral wat betreft de gezondheidsvoorlichting (over roken, voeding, problematisch alcoholgebruik en lichaamsbeweging). Ook zien we een toename van de kleine medische verrichtingen. De rol van de huisarts als eerste contactpunt met de gezondheidszorg 
Groenewegen, P., Schäfer, W., Schellevis, F., Boerma, W. Kernwaarden van Nederlandse huisartsen in internationaal perspectief. Huisarts en Wetenschap: 2020: juli

heeft in Nederland iets aan betekenis ingeboet, vooral waar het gaat om sociale problemen. ${ }^{15}$ In de ervaringen van de patiënten is die afname niet direct terug te zien: bijna $90 \%$ gaf aan met hun huisarts ook persoonlijke problemen en zorgen te kunnen bespreken [infographic en bijlage].

\section{Gezamenlijk}

Bijna een derde van de Nederlandse huisartsen is solist, waarmee huisartsenpraktijken hier nog steeds relatief kleinschalig zijn. In bijna twee derde van de deelnemende landen werken minder huisartsen als solist; in Zweden en Noorwegen zijn bijna geen solistisch werkende huisartsen.

Meestal werken er naast huisartsen vertegenwoordigers van drie andere disciplines in Nederlandse huisartsenpraktijken (de assistente, de poh-somatiek en de poh-ggz). In de helft van de landen is het aantal andere disciplines lager. In België is het niet ongebruikelijk dat een huisarts helemaal zonder enige ondersteuning werkt. Aan het andere eind van het spectrum vinden we Finse en Litouwse gezondheidscentra, waar in de helft meer dan zes andere disciplines werkzaam zijn. ${ }^{16}$ Vergeleken met huisartsen in andere landen werken Nederlandse huisartsen het meest samen met vertegenwoordigers van andere eerstelijnsdisciplines. Behalve met elkaar overleggen Nederlandse huisartsen ook geregeld met praktijkverpleegkundigen, apothekers en thuiszorgverpleegkundigen, en meer dan in andere landen met fysiotherapeuten en diëtisten. ${ }^{11}$

Het is gebruikelijk dat Nederlandse huisartsen een verwijsbrief aan hun patiënten meegeven; in 2012 zei ruim $90 \%$ van de huisartsen dat altijd te doen. Engelse huisartsen doen dit nog iets vaker. Van de Italiaanse en Duitse huisartsen geeft minder dan $10 \%$ aan dat altijd te doen. Ongeveer $60 \%$ van de Nederlandse huisartsen zegt ook (bijna) altijd terugkoppeling uit de tweede lijn te krijgen over een verwezen patiënt. Dat ligt in Engeland en Noorwegen boven de 70\%, terwijl minder dan $10 \%$ van de Duitse huisartsen aangeeft (bijna) altijd terugkoppeling te krijgen. Het werken met verwijsbrieven hangt samen met de beschikbare ondersteuning in de huisartsenpraktijk en de automatisering. Huisartsen die een EPD gebruiken en die vaker met de tweede lijn overleggen, schrijven ook vaker verwijsbrieven. Dit laatste gaat ook samen met terugkoppeling uit de tweede lijn. In landen waar huisartsen een poortwachtersfunctie hebben krijgen ze vaker terugkoppeling over een verwezen patiënt. ${ }^{17}$

\section{Beschouwing}

\section{Belangrijkste bevindingen}

Het QUALICOPC-onderzoek heeft laten zien dat de Nederlandse huisartsenzorg wat betreft de kernwaarden van de huisartsenzorg over het geheel genomen goed functioneert. De zorg is persoonsgericht en de continuïteit binnen de eerste lijn en tussen eerste en tweede lijn is goed, vergeleken met andere landen. Het taakprofiel van Nederlandse huisartsen is breed en op enkele punten ook breder dan twintig jaar geleden. De komst van praktijkondersteuners in Nederlandse praktijken vergroot het interdisciplinaire karakter van de zorg. Vergeleken met andere landen is de samenwerking met de tweede lijn goed, wat samenhangt met de poortwachtersfunctie van huisartsen en met het feit dat patiënten op naam zijn ingeschreven. Nederlandse huisartsen betrekken hun patiënten bij de verwijsbeslissing en zijn daarom misschien beter te omschrijven als gids dan als poortwachter. Het mag een prestatie genoemd worden dat huisartsen in Nederland zeer toegankelijk zijn, gegeven de grote omvang van de praktijken, als we dat vergelijken met andere landen met inschrijving op naam. ${ }^{18}$

Vanwege de relatief korte gemiddelde consultduur wijkt de Nederlandse huisartsenzorg in negatieve zin af van die in andere landen. Overigens vertaalt zich dat niet in een ongunstig oordeel daarover van patiënten. Negatief oordeelde slechts $6 \%$ van de patiënten, een percentage dat overeenkomt met een recente peiling onder Nederlandse burgers. ${ }^{19}$ Een verlenging van de consultduur kan ingrijpende gevolgen hebben voor de benodigde capaciteit en moet daarom zorgvuldig worden 
Groenewegen, P., Schäfer, W., Schellevis, F., Boerma, W. Kernwaarden van Nederlandse huisartsen in internationaal perspectief. Huisarts en Wetenschap: 2020: juli

afgewogen tegen de voordelen ervan. De afgenomen gerichtheid van Nederlandse huisartsen op sociale problematiek sluit geheel aan bij de onlangs meer gespecificeerde kernwaarde 'medischgeneralistische zorg'. Nederlandse huisartsen onderkennen sociale problemen wel, zoals ook aangegeven door patiënten, maar verwijzen patiënten daarvoor mogelijk vaker door naar andere zorgverleners.

\section{Implicaties voor beleid}

Veranderingen in de zorgvraag en het gezondheidsbeleid vereisen een grotere populatiegerichtheid van de eerste lijn. De gevolgen van de transitie van de verantwoordelijkheid voor zorg- en ondersteuningstaken naar de gemeenten en de consequenties van het beleid om mensen zo lang mogelijk zelfstandig te laten wonen, zullen merkbaar worden in de huisartsenpraktijken. Sociale problematiek en de gevolgen daarvan zullen meer aandacht vragen. Goede doorverwijzing van deze patiënten vergt samenwerking. Een meer proactieve opstelling kan doelgerichte preventie bevorderen of ervoor zorgen dat oudere patiënten die gemist dreigen te worden tijdig bereikt worden. Op verschillende plaatsen in Nederland vinden experimenten op dit gebied plaats, waarbij geleerd kan worden van de ervaringen in andere landen.

Het is de vraag of de praktijkomvang en de consulttijd per patiënt bij deze uitdagingen en ambities op hetzelfde niveau kunnen blijven en huisartsen ook in de toekomst patiënt- en populatiegericht kunnen blijven werken.

\section{Veranderingen sinds 2012}

De gegevens voor dit onderzoek zijn grotendeels in 2012 verzameld. Sindsdien hebben zich allerlei veranderingen voltrokken in de Nederlandse huisartsenzorg, zoals de snelle toename van de avondopenstelling van praktijken. Hoewel de kernwaarden begin 2019 zijn herijkt, is het nog steeds nuttig een vergelijking te maken met eerder verzamelde gegevens. De herziene kernwaarden wijken immers niet radicaal af van wat al heel lang de basis vormt van de Nederlandse huisartsgeneeskunde. Bovendien bestaat er geen recenter onderzoek dat de Nederlandse huisartsenzorg vergelijkt met die in andere landen. Recent onderzoek onder burgers over de kernwaarden laat overigens zien dat Nederlanders de huisartsenzorg nog steeds zeer waarderen, wat overeenstemt met de resultaten uit 2012, waarbij de Nederlandse patiënten vonden dat de zorgverlening door hun huisarts slechts weinig verbetering behoefde. ${ }^{9,20}$ De gesignaleerde afgenomen gerichtheid van Nederlandse huisartsen op sociale problematiek zien we eveneens terug in dat onderzoek onder burgers. ${ }^{20}$ Ook de invoering van de basis-ggz op 1 januari 2014 heeft het werk van huisartsen beïnvloed, omdat mensen met alleen psychische problemen voor vergoede zorg naar de huisartsenpraktijk moeten. Patiënten met psychische symptomen, psychische diagnoses en sociale problemen nemen daardoor vaker contact op met hun huisarts. Inmiddels werkt in bijna alle huisartsenpraktijken een poh-ggz. Nadat in 2015 de verantwoordelijkheid voor een deel van de ondersteuning en zorg is overgegaan naar de gemeenten moeten huisartsen bovendien meer tijd besteden aan de samenwerking met wijkteams en gemeenten.

\section{Conclusie}

De onlangs herijkte kernwaarden van Nederlandse huisartsen lijken rond de tijd waarin de gegevens in het QUALICOPC-onderzoek werden verzameld al gerealiseerd te worden, ondanks veranderingen in de zorgvraag en de nog steeds relatief grote praktijken. Vergeleken met collega's in andere landen doen Nederlandse huisartsen het relatief goed op de kernwaarden. De inrichting van het stelsel met inschrijving op naam en de poortwachtersfunctie draagt daaraan bij. Verbetering is onder meer mogelijk wat betreft de tijd die huisartsen voor patiënten hebben en de samenwerking tussen eerste en tweede lijn. 
Groenewegen, P., Schäfer, W., Schellevis, F., Boerma, W. Kernwaarden van Nederlandse huisartsen in internationaal perspectief. Huisarts en Wetenschap: 2020: juli

\section{Literatuur}

1. WHO. Declaration of Alma-Ata. International Conference on Primary Health Care, Alma-Ata, USSR, 6-12 September 1978. Alma Ata: World Health Organisation, 1978.

2. WHO. World Health Report 2008 - Primary Health Care. Geneva: WHO Publishing, 2008.

3. WHO. Declaration of Astana. Global conference on primary health care. Astana 25-26 October 2018. Astana: World Health Organisation, 2018.

4. Schäfer W, Boerma WGW, Van den Berg MJ, De Maeseneer J, De Rosis S, Detollenaere J, et al. Are people's health care needs better met when primary care is strong? A synthesis of the results of the QUALICOPC study in 34 countries. Prim Health Care Res Dev 2019;20:e104.

5. Van der Horst H, Dijkstra R. Woudschoten 2019. Huisarts Wet 2019;62:19-22.

6. Schäfer W, Boerma WGW, Kringos DS, De Maeseneer J, Greß S, Heinemann S, et al. QUALICOPC, a multi-country study evaluating quality, costs and equity in primary care. BMC Fam Pract 2011;12:115.

7. Groenewegen PP, Greß S, Schäfer W. General practitioners' participation in a large, multicountry combined general practitioner-patient survey: recruitment procedures and participation rate. Int J Fam Med 2016;2016:4929432.

8. Schäfer W, Boerma WGW, Kringos DS, De Ryck E, Greß S, Heinemann S, et al. Measures of quality, costs and equity in primary health care: instruments developed to analyse and compare primary care in 35 countries. Qual Prim Care 2013;21:67-79.

9. Schäfer W, Boerma WGW, Murante AM, Sixma H, Schellevis FG, Groenewegen PP. Assessing the potential for improvement of primary care in 34 countries: a cross-sectional survey. Bull World Health Organ 2015;93:161-8.

10. Rotar AM, Van Den Berg MJ, Schäfer W, Kringos DS, Klazinga NS. Shared decision making between patient and GP about referrals from primary care: does gatekeeping make a difference? PLOS ONE 2018;13:e0198729.

11. Schäfer W, Van den Berg M, Groenewegen PP. De werkbelasting van huisartsen: Nederland in internationaal perspectief. Utrecht: Nivel, 2016.

12. Van den Berg MJ, Van Loenen T, Westert GP. Accessible and continuous primary care may help reduce rates of emergency department use. An international survey in 34 countries. Fam Pract 2016;33:42-50.

13. Flinterman L, Groenewegen PP, Verheij R. Zorglandschap en zorggebruik in een veranderende eerste lijn. Utrecht: Nivel; 2018.

14. Schäfer W, Boerma WGW, Schellevis FG, Groenewegen PP. GP practices as a one-stop shop: how do patients perceive the quality of care? A cross-sectional study in thirty-four countries. Health Serv Res 2018;53:2047-63.

15. Schäfer W, Van den Berg M, Boerma WGW, Schellevis FG, Groenewegen PP. Taakprofielen van huisartsen in Nederland en Europa. Huisarts Wet 2016;59:286-91.

16. Groenewegen PP, Heinemann S, Greß S, Schäfer W. Primary care practice composition in 34 countries. Health Policy 2015;119:1576-83.

17. Scaioli G, Schäfer W, Boerma WGW, Spreeuwenberg P, Schellevis FG, Groenewegen PP. Communication between general practitioners and medical specialists in the referral process: $\mathrm{a}$ survey in 34 countries. BMC Fam Pract 2020;21:54.

18. Schäfer W, Van den Berg M, Groenewegen PP. De werkbelasting van huisartsen in internationaal perspectief. Huisarts Wet 2016;59:94-101.

19. Holst L, Brabers A, De Jong JD. Patiënten wederom positief over de bejegening door hun huisarts. Utrecht: Nivel, 2019.

20. Brabers A, De Wit N, Meijman B, De Jong JD. Burgers over kernwaarden en kerntaken huisarts. Huisarts Wet 2019;62:23-8. 
Groenewegen, P., Schäfer, W., Schellevis, F., Boerma, W. Kernwaarden van Nederlandse huisartsen in internationaal perspectief. Huisarts en Wetenschap: 2020: juli

Groenewegen P, Schäfer W, Schellevis F, Boerma W. De kernwaarden van Nederlandse huisartsen in internationaal perspectief. Huisarts Wet 2020;63:DOI:10.007/s12445-020-0760-

0 . Nivel, Utrecht: P. Groenewegen, senior onderzoeker zorgstelsel en sturing, Nivel, en emeritus hoogleraar Universiteit Utrecht, p.groenewegen@nivel.nl; F. Schellevis, huisarts niet praktiserend, voormalig afdelingshoofd Nivel; W. Boerma, senior onderzoeker.

Department of Surgery, Northwestern University, Chicago: W. Schäfer, research assistant professor. Mogelijke belangenverstrengeling: de gegevensverzameling is mede gefinancierd door de Europese Commissie binnen het Zevende Kader Programma (grant nummer 242141).

\section{Tabellen en figuren}

Figuur 1 Antwoord op de vraag: wie beslist er bij een verwijzing waar de patiënt heen gaat?

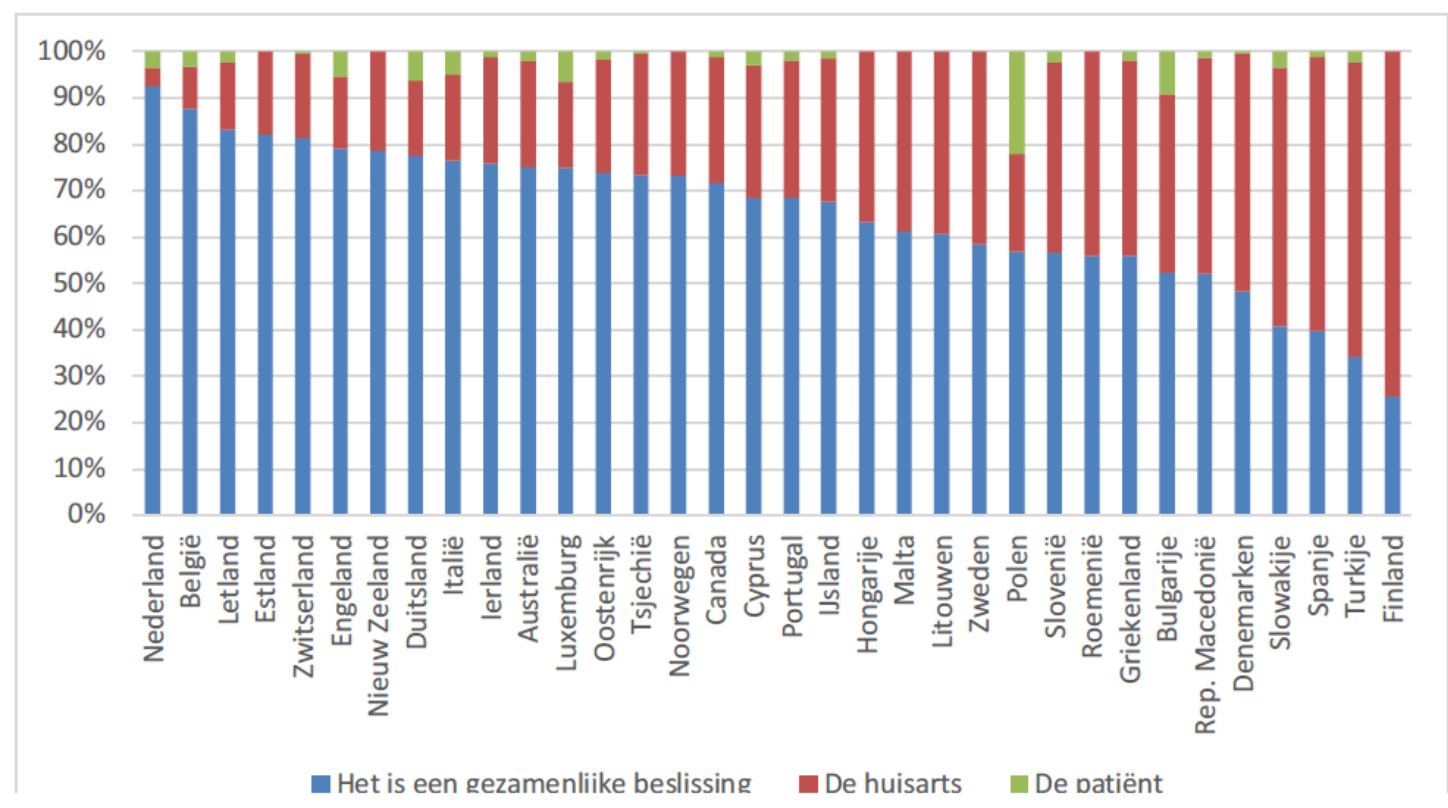


Groenewegen, P., Schäfer, W., Schellevis, F., Boerma, W. Kernwaarden van Nederlandse huisartsen in internationaal perspectief. Huisarts en Wetenschap: 2020: juli

Infographic
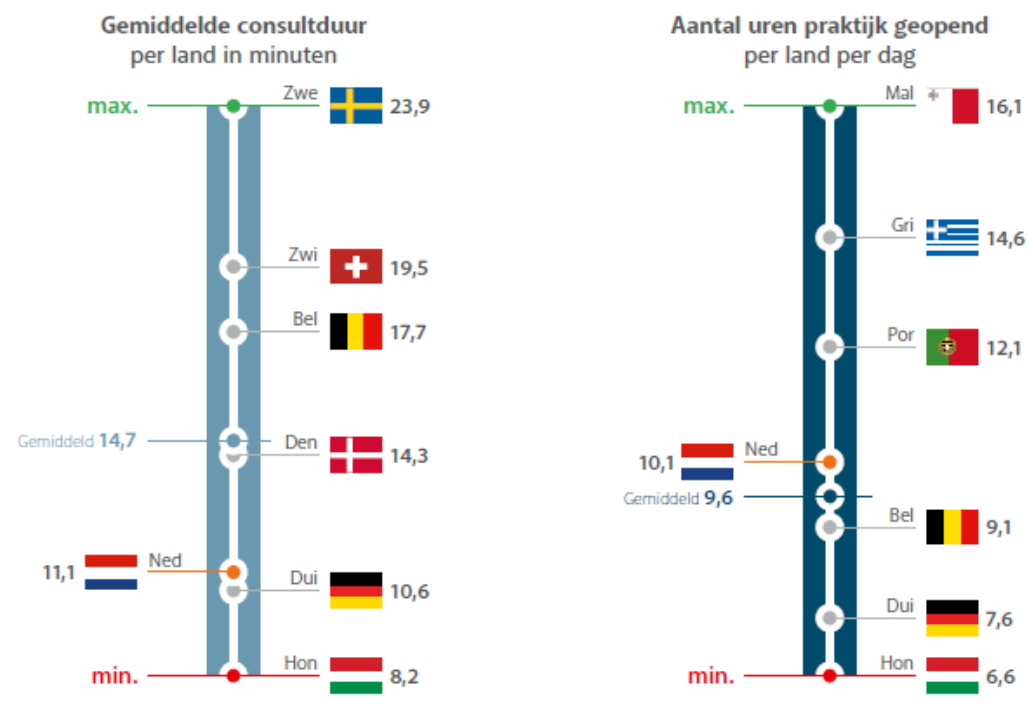

1 maal of meer SEH bezocht

percentage per jaar per land

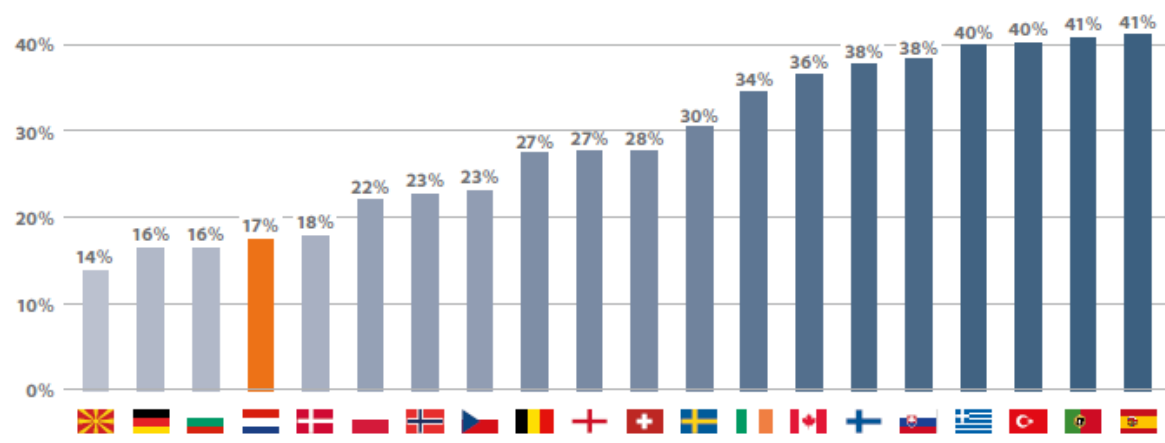

Mac* Dui Bul Ned Den Pol Noo Tsj Bel Eng Zwi Zwe ler Can Fin Slo Gri Tur Por Spa*

Wachttijd voor een afspraak percentage per land

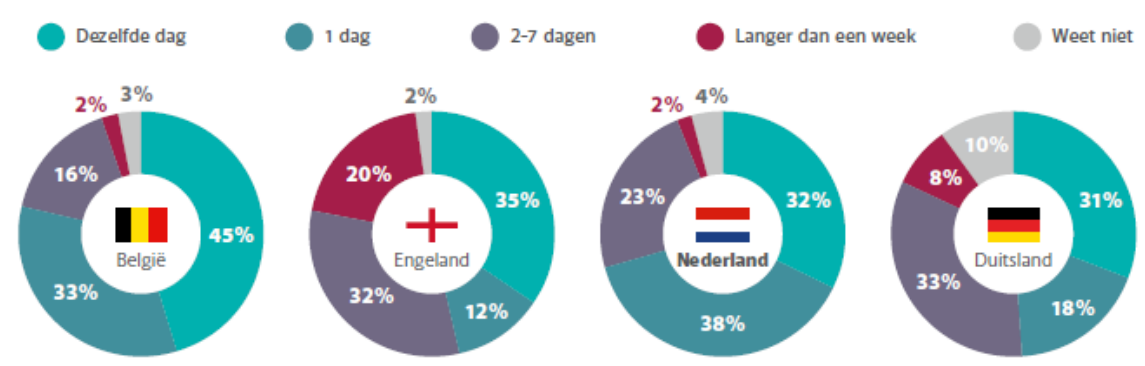


Groenewegen, P., Schäfer, W., Schellevis, F., Boerma, W. Kernwaarden van Nederlandse huisartsen in internationaal perspectief. Huisarts en Wetenschap: 2020: juli

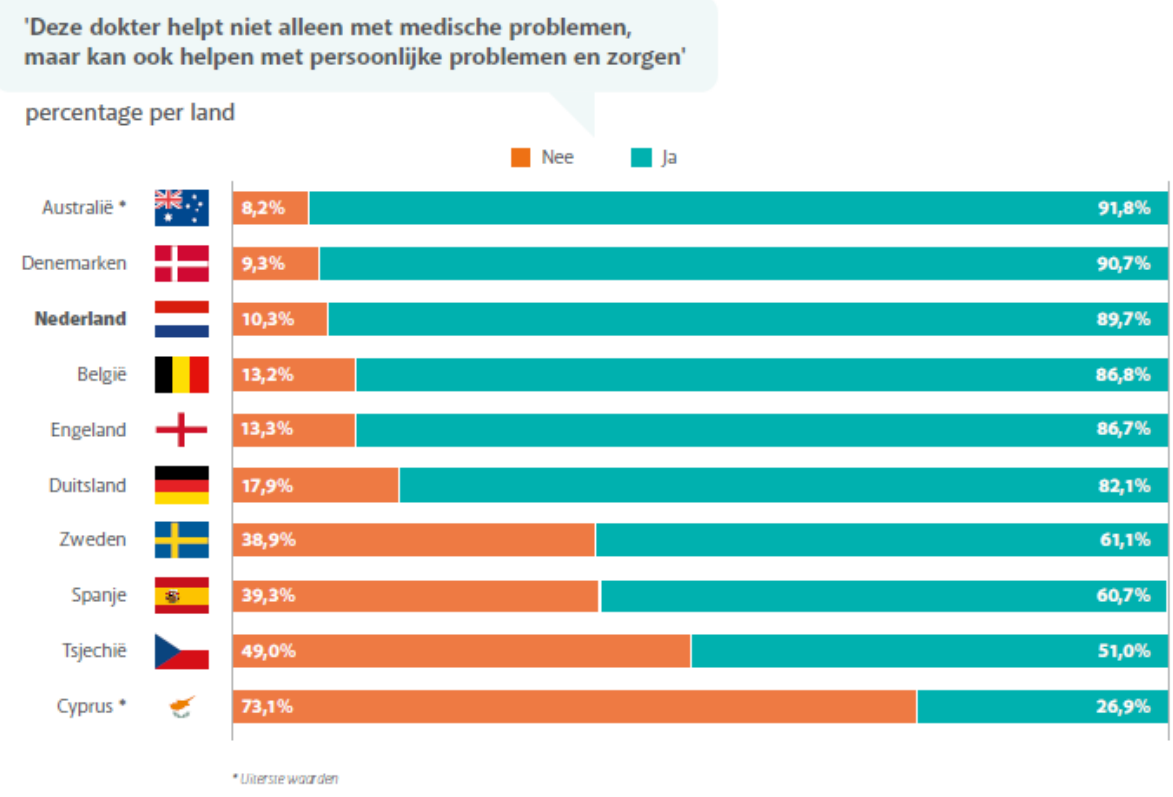


Groenewegen, P., Schäfer, W., Schellevis, F., Boerma, W. Kernwaarden van Nederlandse huisartsen in internationaal perspectief. Huisarts en Wetenschap: 2020: juli

\section{Bijlagen}

\section{Gemiddelde consultduur}

per land in minuten

\begin{tabular}{|c|c|c|c|}
\hline \multirow{2}{*}{ Land } & \multirow{2}{*}{$\begin{array}{c}\text { Consultduur } \\
\text { Minuten }\end{array}$} & \multicolumn{2}{|c|}{$95 \%-\mathrm{BI}$} \\
\hline & & Ondergrens & Bovengrens \\
\hline België & 17,7 & 17,20 & 18,27 \\
\hline Bulgarije & 17,6 & 16,90 & 18,34 \\
\hline Canada & 14,8 & 14,32 & 15,25 \\
\hline Cyprus & 18,3 & 17,06 & 19,57 \\
\hline Denemarken & 14,3 & 13,54 & 15,01 \\
\hline Duitsland & 10,6 & 9,90 & 11,31 \\
\hline Engeland & 11,2 & 10,34 & 11,99 \\
\hline Estland & 16,4 & 15,44 & 17,32 \\
\hline Finland & 23,8 & 23,20 & 24,47 \\
\hline Griekenland & 14,7 & 13,99 & 15,43 \\
\hline Hongarije & 8,2 & 7,48 & 8,94 \\
\hline lerland & 12,8 & 11,94 & 13,61 \\
\hline IJsland & 19,2 & 18,00 & 20,40 \\
\hline Italië & 13,4 & 12,63 & 14,08 \\
\hline Letland & 17,5 & 16,78 & 18,23 \\
\hline Litouwen & 15,9 & 15,17 & 16,59 \\
\hline Luxemburg & 17,6 & 16,38 & 18,82 \\
\hline Malta & 13,0 & 11,67 & 14,27 \\
\hline Nederland & 11,1 & 10,40 & 11,80 \\
\hline Nieuw Zeeland & 14,9 & 14,06 & 15,71 \\
\hline Noorwegen & 18,6 & 17,84 & 19,36 \\
\hline Oostenrijk & 11,7 & 10,92 & 12,53 \\
\hline Polen & 13,7 & 12,96 & 14,40 \\
\hline Portugal & 18,1 & 17,33 & 18,80 \\
\hline Rep. Macedonië & 13,4 & 12,55 & 14,33 \\
\hline Roemenië & 16,6 & 15,91 & 17,35 \\
\hline Slovenië & 9,6 & 8,89 & 10,38 \\
\hline Slowakije & 8,9 & 8,13 & 9,59 \\
\hline Spanje & 8,5 & 8,02 & 9,06 \\
\hline Tsjechië & 10,9 & 10,16 & 11,60 \\
\hline Turkije & 9,3 & 8,67 & 9,91 \\
\hline Zweden & 23,9 & 22,84 & 25,02 \\
\hline Zwitserland & 19,5 & 18,78 & 20,30 \\
\hline
\end{tabular}


Groenewegen, P., Schäfer, W., Schellevis, F., Boerma, W. Kernwaarden van Nederlandse huisartsen in internationaal perspectief. Huisarts en Wetenschap: 2020: juli

\section{Aantal uren praktijk geopend}

per land in per dag

\begin{tabular}{|c|c|c|c|}
\hline Country & Observations & Mean & Standard deviaton \\
\hline Austria & 180 & 6,82 & 3,58 \\
\hline Belgium & 385 & 9,09 & 4,30 \\
\hline Bulgaria & 213 & 10,01 & 4,26 \\
\hline Cyprus & 69 & 8,97 & 4,46 \\
\hline Czech Republic & 211 & 7,98 & 4,95 \\
\hline Denmark & 211 & 8,99 & 4,80 \\
\hline Estonia & 129 & 8,53 & 1,06 \\
\hline Finland & 280 & 8,92 & 3,56 \\
\hline Germany & 229 & 7,59 & 2,23 \\
\hline Greece & 213 & 14,55 & 8,24 \\
\hline Hungary & 210 & 6,64 & 3,49 \\
\hline Iceland & 79 & 9,51 & 3,17 \\
\hline Ireland & 156 & 10,67 & 5,68 \\
\hline Italy & 214 & 7,18 & 3,81 \\
\hline Latvia & 209 & 9,04 & 3,40 \\
\hline Lithuania & 217 & 11,28 & 1,76 \\
\hline Luxembourg & 78 & 9,58 & 4,20 \\
\hline Malta & 69 & 16,06 & 8,67 \\
\hline Netherlands & 237 & 10,05 & 4,41 \\
\hline Norway & 196 & 8,40 & 4,90 \\
\hline Poland & 203 & 10,55 & 2,93 \\
\hline Portugal & 213 & 12,08 & 2,70 \\
\hline Romania & 214 & 7,41 & 2,16 \\
\hline Slovakia & 180 & 8,50 & 2,21 \\
\hline Slovenia & 204 & 10,75 & 6,15 \\
\hline Spain & 425 & 13,99 & 4,38 \\
\hline Sweden & 90 & 8,93 & 2,03 \\
\hline Switzerland & 193 & 8,61 & 1,56 \\
\hline Turkey & 299 & 8,53 & 3,60 \\
\hline England & 143 & 10,26 & 1,36 \\
\hline Australia & 138 & 10,21 & 1,87 \\
\hline Canada & 164 & 8,98 & 1,91 \\
\hline New Zealand & 142 & 9,22 & 1,45 \\
\hline FYR Macedonia & 142 & 9,70 & 2,41 \\
\hline
\end{tabular}


Groenewegen, P., Schäfer, W., Schellevis, F., Boerma, W. Kernwaarden van Nederlandse huisartsen in internationaal perspectief. Huisarts en Wetenschap: 2020: juli

1 maal of meer SEH bezocht

percentage per jaar per land

\begin{tabular}{|c|c|c|}
\hline Land & Niet & 1 maal of meer \\
\hline Austria & 73,8 & 26,2 \\
\hline Belgium & 73,4 & 26,6 \\
\hline Bulgaria & 83,6 & 16,4 \\
\hline Cyprus & 75,3 & 24,7 \\
\hline Czech Republic & 77,0 & 23,0 \\
\hline Denmark & 82,3 & 17,7 \\
\hline Estonia & 61,5 & 38,5 \\
\hline Finland & 62,5 & 37,5 \\
\hline Germany & 73,7 & 16,3 \\
\hline Greece & 60,2 & 39,8 \\
\hline Hungary & 67,1 & 32,9 \\
\hline Iceland & 70,8 & 29,2 \\
\hline Ireland & 65,6 & 34,4 \\
\hline Italy & 71,7 & 28,3 \\
\hline Latvia & 76,8 & 23,2 \\
\hline Lithuania & 70,6 & 29,4 \\
\hline Luxembourg & 65,5 & 34,5 \\
\hline Malta & 70,2 & 29,8 \\
\hline Netherlands & 82,6 & 17,4 \\
\hline Norway & 77,5 & 22,5 \\
\hline Poland & 78,1 & 21,9 \\
\hline Portugal & 59,4 & 40,6 \\
\hline Romania & 80,0 & 20,0 \\
\hline Slovakia & 61,8 & 38,2 \\
\hline Slovenia & 70,2 & 29,8 \\
\hline Spain & 59,1 & 40,9 \\
\hline Sweden & 69,6 & 30,4 \\
\hline Switzerland & 72,4 & 27,6 \\
\hline Turkey & 60,1 & 39,9 \\
\hline England & 72,6 & 27,4 \\
\hline Australia & 70,2 & 29,8 \\
\hline Canada & 63,6 & 36,4 \\
\hline New Zealand & 76,1 & 23,9 \\
\hline FYR Macedonia & 86,3 & 13,7 \\
\hline
\end{tabular}


Groenewegen, P., Schäfer, W., Schellevis, F., Boerma, W. Kernwaarden van Nederlandse huisartsen in internationaal perspectief. Huisarts en Wetenschap: 2020: juli

\section{Wachttijd voor een afspraak}

percentage per land

\begin{tabular}{|c|c|c|c|c|c|}
\hline Land & $\begin{array}{c}\text { Afspraak eerder } \\
\text { vandaag } \\
\text { gemaakt } \\
\end{array}$ & $\begin{array}{l}\text { Afspraak } \\
\text { gisteren } \\
\text { gemaakt } \\
\end{array}$ & $\begin{array}{l}\text { 2-7 dagen } \\
\text { wachten }\end{array}$ & $\begin{array}{l}\text { Langer dan een } \\
\text { week wachten }\end{array}$ & Weet niet \\
\hline België & $45 \%$ & $33 \%$ & $16 \%$ & $2 \%$ & $3 \%$ \\
\hline Polen & 41 & 30 & 25 & 5 & 0 \\
\hline Engeland & 35 & 12 & 32 & 20 & 2 \\
\hline Nederland & 32 & 38 & 23 & 2 & 4 \\
\hline Duitsland & 31 & 18 & 33 & 8 & 10 \\
\hline Nieuw Zeeland & 29 & 35 & 32 & 3 & 1 \\
\hline Zweden & 26 & 10 & 25 & 32 & 7 \\
\hline Zwitserland & 25 & 19 & 28 & 11 & 17 \\
\hline Portugal & 23 & 6 & 26 & 37 & 8 \\
\hline Noorwegen & 23 & 13 & 29 & 25 & 10 \\
\hline Denemarken & 21 & 14 & 35 & 19 & 11 \\
\hline Australië & 21 & 20 & 36 & 17 & 7 \\
\hline Finland & 20 & 6 & 24 & 46 & 5 \\
\hline Roemenië & 20 & 47 & 24 & 7 & 2 \\
\hline Slovenië & 17 & 33 & 45 & 3 & 2 \\
\hline Letland & 16 & 33 & 41 & 8 & 2 \\
\hline Estland & 15 & 25 & 49 & 6 & 5 \\
\hline Canada & 13 & 12 & 34 & 33 & 9 \\
\hline IJsland & 13 & 10 & 39 & 35 & 4 \\
\hline Spanje & 12 & 30 & 50 & 7 & 1 \\
\hline Litouwen & 11 & 18 & 50 & 19 & 2 \\
\hline
\end{tabular}


Groenewegen, P., Schäfer, W., Schellevis, F., Boerma, W. Kernwaarden van Nederlandse huisartsen in internationaal perspectief. Huisarts en Wetenschap: 2020: juli

'Deze dokter helpt niet alleen met medische problemen, maar kan ook helpen met persoonlijke problemen en zorgen'

percentage per land

\begin{tabular}{|c|c|c|}
\hline Land & Nee & Ja \\
\hline Austria & $21,3 \%$ & $78,7 \%$ \\
\hline Belgium & $13,2 \%$ & $86,8 \%$ \\
\hline Bulgaria & $46,7 \%$ & $53,3 \%$ \\
\hline Cyprus & $73,1 \%$ & $26,9 \%$ \\
\hline Czech Republic & $49,0 \%$ & $51,0 \%$ \\
\hline Denmark & $9,3 \%$ & $90,7 \%$ \\
\hline Estonia & $35,4 \%$ & $64,6 \%$ \\
\hline England & $13,3 \%$ & $86,7 \%$ \\
\hline Finland & $18,1 \%$ & $81,9 \%$ \\
\hline Germany & $17,9 \%$ & $82,1 \%$ \\
\hline Greece & $19,3 \%$ & $80,7 \%$ \\
\hline Hungary & $45,1 \%$ & $54,9 \%$ \\
\hline Iceland & $30,1 \%$ & $69,9 \%$ \\
\hline Ireland & $12,2 \%$ & $87,8 \%$ \\
\hline Italy & $20,8 \%$ & $79,2 \%$ \\
\hline Latvia & $33,5 \%$ & $66,5 \%$ \\
\hline Lithuania & $30,7 \%$ & $69,3 \%$ \\
\hline Luxembourg & $18,4 \%$ & $81,6 \%$ \\
\hline FYR Macedonia & $45,3 \%$ & $54,7 \%$ \\
\hline Malta & $49,1 \%$ & $50,9 \%$ \\
\hline Netherlands & $10,3 \%$ & $89,7 \%$ \\
\hline Norway & $13,7 \%$ & $86,3 \%$ \\
\hline Poland & $44,6 \%$ & $55,4 \%$ \\
\hline Portugal & $8,4 \%$ & $91,6 \%$ \\
\hline Romania & $45,2 \%$ & $54,8 \%$ \\
\hline Slovakia & $23,9 \%$ & $76,1 \%$ \\
\hline Slovenia & $37,5 \%$ & $62,5 \%$ \\
\hline Spain & $39,3 \%$ & $60,7 \%$ \\
\hline Sweden & $38,9 \%$ & $61,1 \%$ \\
\hline Switzerland & $12,2 \%$ & $77,8 \%$ \\
\hline Turkey & $40,9 \%$ & $59,1 \%$ \\
\hline Australia & $8,2 \%$ & $91,8 \%$ \\
\hline Canada & $11,1 \%$ & $88,9 \%$ \\
\hline New Zealand & $10,0 \%$ & $90,0 \%$ \\
\hline
\end{tabular}

